\title{
Iran's Fourth Plan: A Partial Assessment
}

\author{
Jahangir Amuzegar
}

Dr Amuzegar served the pre-revolution government of Iran as minister of commerce, minister of finance and ambassador-at-large. He was on the Executive Board of the International Monetary Fund, representing Iran and several other member countries between 1974 and 1980. He has taught at UCLA, the University of Michigan, Michigan State University, the University of Maryland, American University and Johns Hopkins SAIS. He is the author of seven books and more than 100 articles on Iran, oil, OPEC and economic development.

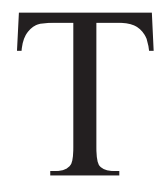

he Islamic Republic's Fourth Economic, Social and Cultural Development Plan (2004/52009/10) came to its unceremonious end on March 21, 2010. ${ }^{1}$ This was to be the first of a four-plan scenario within Iran's ambitious Twenty-year Economic Perspective 2004-2024. According to this perspective, by 2024, after the completion of four five-year plans, Iran was expected to be a fully advanced nation, ranking first among 28 Middle Eastern and South Asian countries in economic, scientific and technological progress, offering a guiding light for the Islamic world while engaging in constructive interaction with the international community. ${ }^{2}$

This review intends to examine the performance of the Fourth Plan against the backdrop of its major socioeconomic objectives. The analysis will be limited to the outcome of the plan itself and does not deal with the totality of events, actions or circumstances in the Islamic Republic during the period. Discussion will also be limited to the areas for which data are available - with a reminder that at no time since the 1979 revolution have official economic statistics been so scarce, inconsistent, doctored or deliberately withheld by the responsible authorities. ${ }^{3}$ Wide differences in published facts and figures also exist among various government agencies, lending much doubt to their accuracy. ${ }^{4}$

\section{THE FRAMEWORK}

The statute mandating the Fourth Plan was approved by the Majlis (the national assembly) on January 25, 2005, to go into effect on March 21. The plan's 52 major objectives in four chapters included almost every coveted national aspiration under the sun: cultural, scientific and technological affairs; social, political, defense and security topics; foreign political and diplomatic relations; and major economic imperatives. Each category enumerated its own specific goals.

In the economic arena, which is the focus of this review, the plan set a large

Middle East Policy (C) 2010, Middle East Policy Council 
number of concrete and specific goals. At the top were (1) rapid and sustained economic growth, job creation and reduced unemployment; (2) curbed inflation and reduced income gaps among various social strata; (3) economic diversification along with increases in human capital, technology and total-factor productivity; (4) selfsufficiency in basic agricultural products;

(5) enhanced international competitiveness and increased non-oil exports; (6) budgetary reforms and reduced reliance on crude-oil exports; (7) privatization of state enterprises and their transfer to the private sector; (8) stabilization of the climate for domestic trade and business; (9) provision of housing for low-income and rural groups; and (10) attention to the supply, maintenance and use of water resources.

The plan's six sections and 15 chapters contained 161 articles dealing with such varied topics as (a) high national economic growth in conjunction with the global economy; (b) environmental protection and regional balance; (c) enhancement of life quality, human security and social justice; (d) preservation of the nation's Iranian/Islamic identity; (e) enhancement of national security and space exploration; and (f) reinvention of the government and improvement of public services. There were upwards of 1,000 specific obligations on the part of government agencies. A final section presented nine quantitative tables involving specific targets in various areas. Targeted figures in each table were based on certain specific assumptions.

In quantitative terms, the plan projected the following concrete targets:

- Population growth shall be limited to 1.4 percent a year.

- Labor, capital and total-factor productivity shall rise by 3.5 percent, 1 percent, and 2.5 percent, respectively, every year.
- Liquidity expansion shall be limited to an annual average of 20 percent.

- Aggregate domestic investment shall rise by 12.2 percent a year, and its share of GDP shall rise from 27.7 percent to 34.7 percent.

- The foreign-direct-investment ratio to GDP shall grow from 0.6 percent to 3 percent by 2010 .

- The foreign-exchange value of the Iranian rial shall be adjusted in line with the difference between domestic and foreign inflation.

- Internal revenue from taxes shall reach 8 percent of GDP by 2010 .

- Current annual government expenditures shall rise by no more than 10 percent in nominal terms.

- The government's current annual budget shall be increasingly financed from nonoil sources.

- Annual budgetary appropriation for research shall reach 2.5 percent of GDP by 2010 .

Based on these presuppositions, the plan promises the following outcomes during the 2005-10 period:

- An average annual real GDP growth of 8 percent;

- An average annual real per capita income rise of 6.6 percent;

- An average annual decline in unemployment by 4.2 percent, with the jobless rate cut by March 2010 to 8.4 percent;

- The average annual inflation rate reduced to 9.9 percent, and to 8.6 percent by March 2010;

- The ratio between the expenditures of the wealthiest 10 percent of families and the poorest 10 percent reduced from 17 to 14 ;

- The Gini coefficient of income disparity reduced to 0.38 ;

- The percentage of the population below 
Middle East Policy, Vol. XVII, No. 4, Winter 2010

the relative poverty line brought down to 7 percent;

- An average annual increase in non-oil exports by 10.7 percent;

- The ratio of national budget to GDP reduced to 10 percent;

- The total number of government employees reduced by 5 percent.

\section{RESULTS}

Despite the government's obligation to submit annual and final reports of the plan's implementation to the Majlis, only one, for the year 2006, was issued. In a speech in late December 2008, President Mahmoud Ahmadinejad gave a brief account of his three-and-a-half-year-old administration without reference to the plan. After accusing his critics of having concocted "40,000 lies" about his government's performance, ${ }^{5}$ he cited a number of accomplishments on his watch. He claimed that GDP had grown 7 percent a year, thanks to four times as many development projects initiated each year and substantial increases in steel, cement, aluminum, coal, oil and gas production. Based on these investments, he claimed, unemployment had been cut from 12.9 percent to less than 10 percent, income gaps among various strata had been reduced, and the Gini coefficient had improved. In the first three years of his stewardship, he continued, the rural sector had enjoyed vastly more natural-gas connections, drinking-water supplies, paved roads, health care and insurance, and ten times as many housing renovations. In other areas, he added, privatization had expanded ten times faster than before. More "justice shares" had been distributed among the poor, and government employees had been reduced. Furthermore, he mentioned, nonoil exports had tripled, foreign debt had been reduced, and there were three times as many patents on inventions. Finally, he boasted that tens of large projects are inaugurated every day, and \$7-\$8 billion in new oil and gas contracts concluded every three months. ${ }^{6}$ He offered no proof for these claims, and no one in the private sector or elsewhere took them seriously.

There has been no further official report pertaining to the Fourth Plan. A tentative appraisal, based on both partial official data and private estimates, is thus ventured here. The accompanying table shows numerical targets of the plan and their estimated realization. A more detailed discussion of the goals and their realization follows.

\section{FROM BAD TO WORSE}

As can be readily seen from the table (on p. 117) and will be further elaborated below, none of the main targets of the plan, with the arguable exception of non-oil exports, have been reached - in many cases not even approached.

\section{Economic Growth}

The plan's realized annual economic growth has been one of its most disappointing outcomes. Based on a projected crude-oil price of $\$ 20$ a barrel, with total oil and gas receipts of $\$ 120$ billion, the economy was expected to grow at an average yearly rate of 8 percent. Yet, despite an actual average oil price of $\$ 68.80 / \mathrm{bbl}$ over the five-year period and a whopping $\$ 340$ billion in oil and gas export receipts, the annual growth rate over the five-year period is estimated to have been no more than 4.3 percent. ${ }^{7}$ Stranger still, the yearly growth rate, which was to accelerate in the last two years of the plan, actually declined! ${ }^{8}$ In fact, toward the plan's end, a combination of structural weaknesses, 
FOURTH PLAN: TARGETS AND PERFORMANCE, 2005-2010

\begin{tabular}{|c|c|c|c|c|c|}
\hline & \multirow{2}{*}{$\frac{1991-2001}{\text { Record }^{1}}$} & \multicolumn{2}{|c|}{ Target } & \multicolumn{2}{|c|}{ Actual } \\
\hline & & 5-year Avg. & March 2010 & 5-year Avg. & March 2010 \\
\hline GDP $^{1}$ & 3.9 & 8.0 & 9.3 & 4.3 & \\
\hline Per capita GDP & 2.4 & 6.6 & & 2.8 & \\
\hline Unemployment $^{1}$ & 4.7 & -4.2 & 8.4 & 11.2 & 14.6 \\
\hline Inflation ${ }^{1}$ & 2.3 & 9.9 & 8.6 & 15.8 & 10.8 \\
\hline \multicolumn{6}{|l|}{ Productivity $^{1}$} \\
\hline Capital & $\ldots$ & 1.0 & $\ldots$ & -1.3 & $\ldots$ \\
\hline Labor & 1.3 & 3.5 & $\ldots$ & 0.76 & $\ldots$ \\
\hline Total Factor & $\ldots$ & 2.5 & $\ldots$ & -0.16 & $\ldots$ \\
\hline \multicolumn{6}{|l|}{ Investment: } \\
\hline Domestic $^{1,3}$ & 4.3 & 12.2 & $\ldots$ & 5.9 & $\ldots$ \\
\hline Foreign $^{3}$ & $\ldots$ & 3.0 & $\ldots$ & 0.075 & $\ldots$ \\
\hline \multicolumn{6}{|l|}{ Exports: } \\
\hline Oil \& Gas ${ }^{2}$ & $\ldots$ & 120.0 & $\ldots$ & 340.0 & \\
\hline Non-oil Exports ${ }^{1}$ & 5.6 & 10.7 & $\ldots$ & 15.6 & $\ldots$ \\
\hline Non-oil Exports ${ }^{2}$ & $\ldots$ & 53.0 & $\ldots$ & 78.0 & $\ldots$ \\
\hline Imports $^{2}$ & $\ldots$ & 185.0 & & 284.0 & $\ldots$ \\
\hline Population $^{1}$ & 1.5 & 1.4 & & 1.48 & $\ldots$ \\
\hline Liquidity $^{1}$ & 27.3 & 20.0 & $\ldots$ & 28.0 & $\ldots$ \\
\hline
\end{tabular}

Source: Central Bank of Iran, Iran Statistics Center, official releases, and author's estimates.

${ }^{1}$ Annual average percentage change during the period

${ }^{2}$ Billions of U.S. dollars, 2004/5 - 2009/10

${ }^{3}$ As percentage share of GDP

resource misallocations and a worsening business climate produced stagflation a simultaneous state of low growth and high unemployment. The situation, commonly referred to as the Dutch disease, was characterized by reduced international competitive ability, anemic growth and higher prices of land, housing and other non-tradable items.

To be sure, given the mere 3.9 percent rate of average real growth during the 1991-2001 period and the Third Plan's inability to reach its anticipated growth target, the 8 percent annual growth anticipated in the Fourth Plan was clearly overly ambitious. The 8 percent target required at least a half-trillion dollars of aggregate investment during the five-year period, which was clearly nowhere to be found. Furthermore, public investment priorities given to politically inspired projects (e.g., nuclear-energy enrichment, military hardware, space exploration, foreign adventures) or allocated to low-return undertakings (e.g., unprofitable airports, water-short dams, low-traffic highways and aid to 
Middle East Policy, Vol. XVII, No. 4, Winter 2010

depressed regions) played a crucial part in the overall outcome. Still further, modern technological improvements in agriculture, competitive new industries, efficient public transportation and environmental protection were badly neglected.

\section{Employment}

High employment also proved to be an elusive goal. Although national unemployment data released by the Iran Statistics Center, the Ministry of Labor, informal workers' associations and private analysts do not match up, all estimates point to a double-digit range during the entire plan period. Official data show that the annual jobless rate gradually declined from 11.5 percent in 2005 to 10.4 percent in 2008 , before rising to 11.9 percent in 2009 and higher in early 2010. Private estimates indicate an increase from 14.7 percent in 2005 to 16 percent in 2007 before declining to 14.6 percent in 2010 . The official national average also reflects single-digit (7-8 percent) unemployment in some provinces and $27-28$ percent in others. ${ }^{9}$ The rate for ages $15-24$ shows 23.3 percent in 2005 and 29.6 percent in $2010 .^{10}$ The labor news agency ILNA places the end-year figure at 18 percent. ${ }^{11} \mathrm{~A}$ former Iranian employers' representative to the International Labor Organization points to a national jobless rate in 2009 of more than 22 percent, and in some provinces more than 45 percent. ${ }^{12}$ Apart from widespread suspicion of deliberate data manipulation, the most obvious reason for the differences between official and private estimates is the fact that the Ministry of Labor counts military draftees, housewives, students and those who work for one or two hours a week as "employed." At the same time, a large number of job seekers have evidently stopped looking for work or decided to continue their education at state universities (at zero opportunity cost) in the hope of finding better chances at a later date. ${ }^{13}$

Widely regarded as the regime's Achilles' heel, job creation was the special focus of the planners. They envisaged the creation of more than 900,000 jobs each year, for a total of 4.8 million, hoping to bring the unemployment rate to 8.4 percent by March 2010. However, even the disputed low-double-digit official unemployment rate of 11.9 percent in March 2010 was still far above the target of 8.4 percent. Loans to the so-called "quick-return projects" were initially the administration's principal way of stimulating job creation. Improved distribution of credit and higher non-oil exports were other means. Appearing before the Majlis in mid-August 2010, the minister of labor and social affairs testified that during the plan period, some $\$ 21.5$ billion were lent to these enterprises, and more than 968,000 jobs were created. A protesting deputy member, however, pointed out that the employment target for these ventures had been 3 million, more than three times the realized figure. Furthermore, some 70 percent of the loans were given to already self-employed borrowers; thus, no more than 300,000-400,000 new jobs - an average of two additional workers per unit - were actually created. He also referred to reports by the Central Bank and the National Inspection Organization regarding flagrant deviations by the borrowing enterprises from their stated proposals. ${ }^{14}$ Still further, he noted that more than 300,000 of these small businesses were on the verge of bankruptcy, needing additional government assistance. ${ }^{15}$ Another opposition deputy pointed out that that borrowing enterprises have been able to pay back only 10 percent of their loans so far. ${ }^{16}$ 
While the jobless numbers cited by the authorities widely differ from private estimates, the fact remains that, by the end of the period, an estimated 3.5-5 million people - the largest number in the country's post-revolution history - were out of work. Three-quarters of a million among the unemployed were reportedly farm workers who had lost their jobs due to reduced government support, credit shortages, excessive agricultural imports and increased mechanization. ${ }^{17}$

\section{Inflation}

The plan's record in taming inflation has been somewhat better. The official consumer price index at President Ahmadinejad's inauguration in June 2005 was 11.1 percent. A series of expansionary fiscal and monetary policies pursued under the new president's direction during 2005-07 pushed the index to 25 percent in September 2008. Thereafter, due to a reduction in annual liquidity growth from 40 percent a year to 16 percent by 2008 , a severe tightening of credit policy by the Central Bank, and the global financial crisis, the index began to decline. The official consumer price index in March 2010 is given as 10.8 percent. ${ }^{18}$ Private estimates place the figure at 20.5 percent. ${ }^{19}$ The average official annual rate during the plan came down to 15.8 percent - far above the target. Private estimates show upward of 22 percent. In any case, despite official pride in combating inflation, Iran's rank in 2010 among 222 countries and territories was 216 , with only six having a higher rate. ${ }^{20}$

\section{Productivity}

Failure to enhance productivity has been another disappointment. According to the plan, some 2.5 percent of the projected
8 percent real annual GDP growth was to be realized from increases in total-factor productivity and 5.5 percent from new investments. Yet, according to the director of Iran's Productivity Society, during the first three years of the plan, only 1 percent of growth could be attributed to such improvements. ${ }^{21}$ The five-year figure, according to private estimates, shows only a minuscule increase in labor productivity and negative figures for both capital and total factor. Suggested reasons for the low labor figure include inadequate employee qualifications, lack of personal interest and enthusiasm, acceptance of positions simply to earn income rather than be useful or creative, lack of sufficient job security, and the absence of job supervision. According to one estimate, there has been only one hour of productive work out of the daily eight in both government and private occupations. ${ }^{22}$ Suspected culprits for negative figures in the case of capital and total-factor productivity may be found in the mismatching of formal education and national economic needs, ${ }^{23}$ inadequate training, use of antiquated technology, poor selection of projects, and diversion of research into non-civilian activities.

\section{Investment}

The behavior of aggregate investment has also been among the least successful of the plan targets. Its woefully small amount has been the principal source of slow growth, high unemployment and doubledigit inflation. Under the plan, investment growth was to average 12.8 percent a year in real terms and reach nearly 35 percent of GDP. Actually, the annual rate, except for the year 2005, seldom exceeded 7 percent, and the five-year average came to only 6 percent. A number of economic factors are cited as the main impediments: declining 
Middle East Policy, Vol. XVII, No. 4, Winter 2010

capital returns due to reduced international competitiveness, profitability of short-term trade and stock-market speculation, difficulties of domestic investment financing due to the banking system's capital inadequacy and huge non-performing assets, ${ }^{24}$ greater investment opportunities offshore, and ever-changing government regulations. Increased inroads by the Islamic Revolutionary Guard Corps into lucrative public projects - infrastructure, oil and gas, telecommunications and others - on special non-competitive government contracts also tended to discourage domestic participation by private investors. ${ }^{25}$ Foreign direct investments that were expected to reach 3 percent of GDP by 2010 were no more than a small fraction of the target. The estimated total for the period of less than $\$ 9$ billion never even approached the goal, due mainly to a deteriorating business climate, foreign sanctions and assorted bureaucratic red tape. ${ }^{26}$ At the same time, there have been widespread reports of as much as $\$ 3.5$ billion in capital flight per year. ${ }^{27}$ And Iran's own foreign joint ventures in the Persian Gulf region and Latin America are reported to have reached $\$ 800$ million. $^{28}$

\section{Reducing Poverty}

The plan's success in reducing poverty and improving domestic income distribution is highly disputed and controversial. The extent of poverty in the country is still subject to extensive debate. The minister of welfare and social security in charge of poverty eradication has repeatedly refused to divulge the numbers, arguing that such information is useless and of no significance. President Ahmadinejad and a small coterie of his associates claim that there is now no "absolute poverty" in Iran and that domestic income distribution has improved. Most private analysts differ. Measured by three standard criteria changes in family expenditures relative to income, the expenditure ratio of the top 10 percent of the population to the bottom 10 , and trends in the Gini coefficient - it is widely believed that poverty has actually increased and income distribution worsened. Based on official data, both urban and rural family expenditures went up during 2005-10, while income did not keep pace. ${ }^{29}$ Data released by the Central Bank also show that the Gini coefficient steadily deteriorated, from 0.3996 in $2004 / 5$ to 0.4045 in $2007 / 8$. At the same time, the ratio of the top 10 percent of income recipients' expenditures to those of the bottom decile rose from 14.6 to 15.9 during the same period. ${ }^{30}$ Contrasting these reports, the government's data base claims that in the plan's last year, the Gini coefficient has declined to 0.3859 , and the ratio of top-to-bottom income recipients decreased to 13.5 times. $^{31}$ Estimates by the World Bank and Iran's own Central Bank for different plan years show that between 8 percent and 19 percent of the total population fall below various poverty lines. ${ }^{32}$ The opposition press puts the absolute poor between 29 and 32.5 percent, or 20 million. ${ }^{33}$ In short, there is no indication that the plan's goal of 7 percent poverty reduction has been reached. Moreover an interesting phenomenon in the Iranian case is that some 67 percent of urban and 52 percent of rural families categorized as poor were headed by an employed person. Low wages rather than joblessness were the apparent cause. ${ }^{34}$

\section{Foreign Exchange}

The foreign exchange value of the Iranian rial, which had to be adjusted in line with "the gap between domestic and 
foreign inflation" was not acted upon. As it turned out, while the official domestic consumer price index during the fiveyear period rose by nearly 80 percent (compared with 15-20 percent for Iran's major trade partners), the average annual rial/dollar value went up by less than 11 percent - from Rls. 9026=\$1 in 2005 to RLs. $1040=\$ 1$ in 2010 . The actual misalignment was even greater, since official inflation figures normally underestimated the true price changes in the market, and the initial exchange rate was also not in equilibrium. By a rudimentary calculation, the exchange value of the U.S. dollar in March 2010 should have been between R1s. 22,000 and 24,000 instead of hovering around Rls. 10,000.

The results of this significant real over-valuation have been a severe blow to domestic producers in their competition with foreign rivals and a hefty subsidy to foreign farmers and manufacturers. Iran's relatively cheap foreign exchange has pushed imports during the five-year period to $\$ 284$ billions: 2.8 times that of the Third Plan, and 53 percent larger than the planned target. Of greater significance is the fact that imports of consumer items were 36 percent larger, and capital goods 49 percent smaller, than in the previous plan. ${ }^{35}$ In addition to legitimate imports, authorities confiscated an estimated \$20 billion worth of smuggled goods in 2009, up from $\$ 13$ billion in 2007-08 and \$6 billion in 2004-05. ${ }^{36}$ The imports, while helping to rein in galloping inflation, successfully competed against domestically produced goods and lowered production in a large number of local industries to only 30 to 40 percent of capacity. Other clear consequences of the massive imports were a worsening of Iran's non-oil trade balance, capital flight and reduced foreign direct investments. Furthermore, it is estimated that each $\$ 1$ billion of extra imports threw out an estimated 100,000 workers and raised the country's dependence on food imports. Incentives for steadily increasing imports (on top of the highly overvalued exchange rate) were such factors as high domestic inflation, low industrial and farm productivity, and the profitability of out-sourcing, whereby domestic companies shifted all or a major part of their production to lower-wage or cheaperexchange-rate countries (like China) and limited their domestic value-added to local packaging and trademarking. ${ }^{37}$

\section{Non-oil Exports}

The performance of non-oil exports, at first glance, has been the brightest spot in the plan. The share of these exports in Iran's total annual foreign sales was targeted to rise 10.7 percent annually and to reach $\$ 52.8$ billion (33.6 percent of total exports) by 2010 . Actually, the total for the period amounted to $\$ 78$ billion, having increased at 15.6 percent a year. Due to a spectacular rise in oil and gas exports, however, the 33.6 percent target was missed; the outcome was only 18.5 percent. Furthermore, nearly 45 percent of the "non-oil" exports normally consisted of petrochemicals and other gas-based condensates. ${ }^{38}$ And the ratio of non-oil exports to GDP, which was expected to be 10 percent, reached only 4.8 percent.

Other ancillary objectives of the plan also generally missed their targets. A Majlis deputy involved in the parliamentary investigation of the plan's performance points to a 30 percent deviation from overall targets and 80-100 percent failures in certain cases. ${ }^{39}$ While concrete data for the quantitative evaluation of these targets are not available, scattered officials and 
Middle East Policy, Vol. XVII, No. 4, Winter 2010

private reports offer the following clues:

- The ratio of taxes to GDP, which was to reach 8 percent in the fifth year, was stuck at less than 7 percent.

- The budget's reliance on oil-export receipts for current expenditures, which was to be gradually reduced, actually rose. ${ }^{40}$

- Despite the mandate requiring the government to eliminate its debt to the banking system by 2010, its obligations actually increased.

- While a state spokesman claims that total government employees had been cut by 160,000 (7.9 percent), ${ }^{41}$ private analysts show increases in total figures.

- The plan's mandate regarding the Oil Reserve Fund's replenishment and drawdown cannot be evaluated since the government protects the fund's balances as state secrets. Various unofficial figures mentioned by Majlis deputies indicated a balance of less than $\$ 10$ billion in March 2010. Had the government met the plan's mandate for depositing extra annual oilexport income in the fund, the balance should have been more than $\$ 100$ billion.

- The plan's requirement for gradual upward annual price adjustments of subsidized products was totally scuttled by the sixth Majlis.

- The objective of accelerated privatization was not achieved. Some 50 percent of the $\$ 70$ billion in privatized assets of 330 state enterprises during the five-year period consisted of the distribution of "justice shares" among poorer strata. ${ }^{42}$ Another 25 percent was ceded to government agencies (the Social Security Fund and the Pension Fund) in lieu of delayed government budgetary contributions. Only 13.5 percent was sold to the private sector, through the Tehran Stock Exchange. And more than 75 percent of the management of the ceded enterprises remained in state hands. ${ }^{43}$

\section{SEARCHING FOR CLUES}

The unflattering performance of the Fourth Plan has, to a large extent, been a predictable outcome of its own unrealistic assumptions, inadequate input/output calculations, and overly ambitious targets. Nevertheless, the Ahmadinejad government's share in ignoring the plan's mandates and disregarding its provisions can by no means be ignored or belittled. It is true that the Fourth Plan was prepared and approved during the Khatami administration, and the document was placed at the new president's door without his involvement or input. But he not only refused to endorse the plan's directives, he actually undermined its operation through a series of countermeasures. A stunning manifestation of this lack of interest, if not actual opposition, was the abrupt closing of the 60-year-old government Plan Organization in charge of Iran's five-year planning and the annexation of its operation to the president's executive office.

The overall blame for the plan's subpar accomplishments, however, must be shared by (1) Ahmadinejad's own belief system and leadership style; (2) the poor qualifications of his economic team; and (3) the worsening climate for investment and productive activities during the period.

\section{The President's Role}

An explanation for the plan's disappointing performance - and its identification as the least successful of the Islamic Republic's post-revolution planning points to the president's own complex persona, his messianic ideology, quixotic behavior, provocative statements and blunt language. ${ }^{44}$ The totality of these traits has been largely responsible for blunting his authority at home and damaging Iran's position and prestige in the world, thus 
undermining the plan's overall chances for success.

Mahmood Ahmadinejad is often described as a sui generis phenomenon. Yet he is no enigma. He is an ambitious politician with a mammoth ego characteristic of successful people of humble origins trying to be regarded as important global players. $\mathrm{He}$ is also obstinate, excitable and intransigent, eager to pick a political fight for his "cause." He has reviled and discredited his domestic political rivals, mocked everyone in the secular and religious establishments who disagreed with him, and disparaged foreign leaders and governments that did not support his policies. ${ }^{45}$ Even some of his supporters accuse him of being exclusive, dismissive of friendly advice, and unduly reliant on a small circle of relatives and trusted comrades-in-arms. No Iranian president in the 32-year history of the Islamic Republic has been so widely criticized at home or so savagely vilified abroad. No other has faced so much difficulty in obtaining a Majlis' vote of confidence for his cabinet choices or so many obstacles in garnering approval for his bills, despite the fact that a majority of the assembly members, called "principalists," have been his camp followers. He has been chastised and overridden by the supreme leader (his staunchest supporter) more times than any other government office holder. Even some of his foreign colleagues and friends, like Cuba's Fidel Castro and Brazil's Lula da Silva, have chastised him for his anti-Semitism.

As an Islamic ideologue and absolutist, Ahmadinejad considers the current world order oppressive and unjust, the West's wealth and power based on its pillaging poor nations and usurping their livelihoods. In his view, "Western society, dominated by liberal democracy, a free-market economy and moral relativism" has a "dark future." ${ }^{46}$ In a long and abstruse discourse at a privatization conference in Tehran, he said: "Western materialistic and capitalist economic science - based on individualism, unfettered competition and pursuit of profit - is at a dead end, since it is conducive to widening income gaps and social conflicts. We, in the Islamic Republic, are bent on establishing a unique Iranian/Islamic and moral-based economics devoted to the uplifting of human personality, instead of creating an economic man." ${ }^{\prime 47}$ With such ideas, and as a fervent anti-Western, anti-capitalist and anti-liberal ideologue, he was thus fundamentally opposed to the Fourth Plan, prepared by Western-trained economists, as alien and un-Islamic. The clearest reflection of this posture is his first vice-president's statement calling the plan document "a liberal scheme based on humanistic ideals" and not even "worth recycling its paper." 48

Ahmadinejad's singular behavior denouncing Western foibles at international gatherings, writing repeated letters to world leaders without receiving answers, inviting American Presidents Bush and Obama to face-to-face televised debates, and advising various heads of state on how to govern their countries - has made him the laughing stock of American late-night comedy shows and a prominent subject of ridicule in the Western media. He's the first Iranian president in the 32-year history of the Islamic Republic to congratulate an American head of state on his successful election. His message to Presidentelect Barack Obama, however, consisted mostly of a pedantic lecture about necessary changes in U.S. foreign policy. Platitudes such as the primacy of "public interests and justice" over "the neverending demands of a selfish minority," the 
need to replace "militarism, occupation, bullying and discrimination" with "justice, friendship and non-interference in other countries' affairs," and, finally, the necessity of "changes in American policy and conduct" filled the rest. The letter's subtext was that the Islamic Republic expected the new president to undo the Bush "evils," adopt a new stance, and treat Iran with due respect and equality. ${ }^{49}$ Later on, responding to President Obama's "outstreatched hand for his unclenched fist," he laid out the preconditions for talks with the new administration as follows: the U.S. president must apologize and compensate for America's "past crimes" against the Islamic Republic; withdraw U.S. forces from overseas and refrain from interfering in other nations' affairs in order to prove his pledge of "change" - and stop supporting Israel. ${ }^{50}$

Another manifestation of his inconsistent behavior has been his attitude toward the United Nations. After repeatedly castigating the UN Security Council as unjust, illegitimate and under Washington's thumb, he sought Iran's membership in the Council for the 2009-10 term, claiming that the Islamic Republic had the full support of the 118 members of the NonAligned Movement for the position. The result was somewhat humiliating, as only 32 nations (17 percent) supported the Islamic Republic's candidacy, and 158 members voted for Japan. Again, while having repeatedly called the Security Council sanctions "illegal, ineffective and a used paper towel to be thrown into the waste basket," ${ }^{51}$ he launched a concerted effort to stop a fourth round of sanctions in early June 2010 through personal travels and promises of financial aid to non-permanent members of the Council. But, once the fourth UN resolution was passed by a clear majority of the 15-member board, he called it the manifestation of "cowboy logic." 52 Then, addressing the Council in obvious anger, he said, "Go issue as many sanctions resolutions as you can until weeds start growing under your feet;" and "go impose as many sanctions as you want until your sanctions-issuing capacity explodes" (a tasteless equivalent of "till hell freezes over"). In every subsequent actual or implied sanctions threat, he has uttered similar nasty words.

At an OPEC summit in mid-2008, calling the U.S. dollar "a worthless piece of paper," ${ }^{53}$ he announced Iran's switch to the euro and asked other OPEC members to demand euros instead of dollars for their crude-oil sales, declaring the proposal "a revolution in oil relations." While the proposal brought no favorable reaction from other delegates, he ordered Iran's Central Bank to change its dollar reserves into euros, and asked Iran's oil customers to pay in euros instead of the customary dollar. Two years later, on May 31, 2010, due to a decline in the euro against the U.S. dollar, the Central Bank began to gradually convert some of its exchange reserves back into gold and dollars. ${ }^{54} \mathrm{As}$ a result of the two shifts, the bank reportedly took a hefty loss.

Ahmadinejad's frequent speeches — consisting mainly of screeds against Western imperialism, global capitalism, Israel and Zionism, and jingoistic talk about Iran's becoming "a real and true superpower" 55 - make headlines daily in Iran and are often reported in the world media. Turning facts on their head, in mid-November 2008, he claimed that the people of Iran and Ayatollah Khomeini were instrumental in the breakdown of the former Soviet Union. Then he added, "I give you the great news that the second part of the world's bipolar structure (i.e., the United 
States) will also crumble soon due to Iran's challenge." ${ }^{56}$ His belief in Iranian exceptionalism led him to tell a sympathetic audience in Kerman during his 2008 countrywide tour: "Today Iran is the most glorious, most beloved and most powerful nation on earth," and "all global equations are influenced by Iran's decision." 57 In a speech before the Islamic World Publishers in mid-summer 2010, he said: "We in Iran are not out to save the world of Islam; we want to rescue the entire humanity." 58 Giving his fanciful speeches an air of vacuity and even farce, he said in a speech at a Tehran seminar: "Currently, Iran is, without a doubt, the most powerful and important nation on earth" and has the final say on world affairs. ${ }^{59}$ Branding his own disputed June 2009 re-election as "the harbinger of a global revolution," he called on the Islamic Republic "to launch its universal mission." ${ }^{60}$ The final irony was that, while Iran's own Fourth Plan had failed to accomplish any of its major objectives by the fourth year of implementation, he boasted that Iran is "the only country with the potential and the talent to introduce a new economic model based on justice and humane values to solve the world's economic crisis." ${ }^{61}$

The president's claims about the Islamic Republic's global power and popularity proved fanciful when a 2008 poll conducted by Aljazeera Television of more than 27,000 viewers indicated that 90 percent of Arabs considered the Islamic Republic their enemy. ${ }^{62}$ Another poll by the British Broadcasting Corporation in early 2009 , involving nearly 14,000 individuals in 24 countries, showed that some 56 percent of respondents regarded the Islamic Republic as "the number-one country with a negative influence on world affairs." ${ }^{63}$ Similar polls by World Public Opinion and Pew
Global Attitudes also found Iran among the world most negatively viewed countries." ${ }^{64}$

Ahmadinejad's use of derogatory Persian words, expressions and slogans has also been a cause of great embarrassment to his educated supporters and heaven-sent manna to his critics. Although capable of using more refined language, he often resorts to what a literary critic has characterized as " impolite, rude, vulgar and insulting" - the type of language used by the "lumpen proletariat, red-necks and bullies." 65 It was for one such utterance that Iran's judiciary chief admonished him to use more "sober, dignified and fair" language." ${ }^{66}$ This manner of speaking, however, in most experts' opinion, has been deliberately used to show his solidarity with the oppressed and the disenfranchised "wretched of the earth."

Unpredictable and controversial behavior, bizarre statements, wild claims, crude proposals and politically incorrect language have kept Ahmadinejad in the global limelight and doubtless immensely satisfied him as a showman. His toughtalking style against the arrogant and affluent West has also made him a hero in the poorer quarters of Cairo, Kabul, Islamabad and Jakarta. Yet almost everywhere else in the global community he has been perceived as irrational, unstable and an unfit interlocutor. His inflammatory statements have also discredited Iran and its government and worked against the country's national interest. By squandering Iran's legitimate prestige on empty hyperbole, he also caused irreparable damage to the plan's chances for success.

\section{The Team's Share}

Part of the blame for the Fourth Plan's poor results is also attributable to the president's cabinet ministers, assistants 
Middle East Policy, Vol. XVII, No. 4, Winter 2010

and advisers. Ahmadinejad's unsophisticated, dictatorial and crass demeanor have made it difficult for him to work with people outside his own circle of friends and cronies. The president's team, in turn, has been widely regarded as mediocre, inept, unqualified and worse. ${ }^{67}$ Ahmadinejad, a former Islamic Revolutionary Guard commander himself, has replaced the large segment of Iran's technocracy that was nurtured under the stewardship of Presidents Rafsanjani and Khatami with his former comrades from the military and security forces. As many as 14 of the 21 members of his cabinet had been guard officers at one time or another. Nearly the entire cadre of well-trained and worldsavvy technocrats familiar with global strategic, political and economic affairs has been prematurely retired, dismissed, imprisoned, silenced or enticed to leave the country. Their replacements have frequently lacked sufficient expertise in their fields. Some have had tarnished financial reputations. Two or three turned out to have falsified their educational qualifications. And they all have been imbued with an early post-revolutionary mentality illsuited for twenty-first century tasks. These deficiencies have caused one-fourth of all Ahmadinejad's nominees to be rejected by the Majlis at one time or another; nine of his 21-member cabinet were replaced. ${ }^{68}$ Some were impeached or dismissed; others resigned out of frustration, blaming the president for their failings.

\section{Inhospitable Business Climate}

A lengthy report by a group of university economists, addressed to the president and the Majlis in October 2008, thoroughly dissected and analyzed the administration's responsibility for the Fourth Plan's poor performance. The report underscored, among other problems, the government's fundamentalist ideology; simplistic assumptions about the economy; preference for trial and error instead of careful preparations; prioritizing loyalty over expertise, emotion over rationality and perception over reality; converting serious goals into populist slogans; treating leaders' preferences as popular wishes; rejecting expert advice; neglecting entrepreneurship and creative thinking in favor of imitation; de-emphasizing the rule of law; and causing a widening gulf between people and government. ${ }^{69}$

These socioeconomic shortcomings coincided with the most politically tense period in the Islamic Republic's peacetime history. The crisis-ridden atmosphere was in part home-grown and in part externally based. At home, President Ahmadinejad, strongly supported by the security and military forces and frequently backed by Supreme Leader Khamenei, was emboldened to pursue a maverick dictatorial leadership style. He repeatedly quarreled with the Majlis and its speaker on such issues as enforcement of the assembly's statutes, reform of consumer subsidies, financing of the Tehran metro, arbitrary closing of various national councils, observance of daylight-saving time, the status of Azad University and the number of national holidays. ${ }^{70}$ Even some of his supporters in the Majlis accused him of ignoring or evading the laws. ${ }^{71}$ Others hinted at a possible impeachment motion against him. He refused to attend the Expediency Council's sessions ex-officio because of his differences with ex-president Rafsanjani, its chairman. He angered the powerful ayatollahs and the clerical establishment in Qom over some of his appointments as well as the enforcement of certain tenets of the Islamic moral code (e.g., men shaving their beards or wearing ties, women attending 
sports events in Tehran stadiums). There were unconcealed differences between him and the powerful judiciary over prosecuting corruption. He angered the bazaar merchants and their religious offshoot, the Motal-e-feh party, over taxes and business regulations. And his open enmity towards his political rivals continued unabated.

This tension-filled political environment, where one branch of the government was in open conflict with the other two, coincided with a period of rising sociopolitical tension occasionally beyond the president's own wishes and control. Reversing Khatami's open-society policies, a movement toward further Islamization of Iranian society got underway, involving revisions of Iranian history, changes in school curricula, increased budgets for religious institutions, replacement of national holidays with religious ones, and similar faith-based policies. A brutal crackdown on political dissent created a highly uncertain economic climate: wholesale closure of newspapers; arrest and incarceration of journalists, bloggers and civil-rights advocates; increased harassment of civil-society leaders and NGOs; intensified discrimination against women; ${ }^{72}$ and massive purges of university professors. ${ }^{73}$

Also partly responsible for aggravating the crisis were external pressures and sanctions. During most of the Fourth Plan period, the Islamic Republic faced increasing global isolation and repeated worldwide sanctions due to its pursuit of a controversial nuclear-energy policy and unwavering support of the "Palestinian cause." Abandoning the Khatami administration's policy of dialogue and cooperation with the West, the Ahmadinejad government became entangled in confrontation and brinkmanship with the United States, the European Union and ultimately the UN Security Council. Invoking its sovereign rights under the Nuclear NonProliferation Treaty (NPT), the Islamic Republic insisted on being able to enrich and stockpile uranium at home for its future energy needs. ${ }^{74}$ Failing to convince the international community of its peaceful intentions during the plan's life, Iran was slapped with three consecutive UNSC sanctions resolutions - in 2006, 2007 and 2008 - to curb its program. By making uranium enrichment an issue of national independence, honor and prestige, the administration contributed to Iran's increasing isolation and alienation. Accused of helping certain anti-Israeli groups in the Middle East, Tehran was also labeled by the United States the number-one state sponsor of terrorism and was further unilaterally sanctioned in several other ways.

The pernicious atmosphere of radical confrontation with the West resulted in a shift of trade and investment from traditional partners in Europe and North America toward less lucrative sources and lower-quality products and technologies in East Asia and a group of radical anti-Westerners in Latin America and Africa. Overt quarrels and recriminations with Washington and Tel Aviv, resulting in daily rumors of imminent American or Israeli military attacks on Iran's nuclear facilities, created a dysfunctional economic environment of uncertainty and fear hardly conducive to long-term business activity. The inhospitable climate, in turn, discouraged productive economic activity and investment at home and encouraged capital flight. Funds were steadily diverted from long-term projects toward speculative short-term activities, gold and foreign-exchange transactions, and forays into the Tehran Stock Exchange, whose price index rose from 9,460 in 2005 to 12,540 in early 2009 . 
While Iranian government officials routinely claim that the UN and U.S. sanctions have had no adverse impact on the Iranian economy, there is little doubt that, even if sanctions involved no actual losses, they certainly had plenty of potential negative consequences. On one rare occasion, a high oil-ministry official told the ILNA news agency that the costs of the country's energy projects had doubled due to the difficulties in finding needed supplies, technology and capital - thus delaying the projects' completion. ${ }^{75}$ A former director of the National Iranian Oil Company has asserted that the Islamic government's inability to obtain new technologies in the West, its lack of access to major world capital markets, and its failure to sell its own energy bonds abroad are seriously threatening the fate of Iran's oil and gas industry. ${ }^{76}$

\section{A LOOK BACK}

In retrospect, the ultimate reasons for the Fourth Plan's disappointing performance were not only the fact that the Ahmadinejad government was opposed to its underlying principles or that it ignored its mandates, but that it also had no strategy of its own. It simply drifted from one slogan to another without establishing a clear direction for action. While opposing the plan's emphasis on liberalization, price and wage decontrol, reliance on the free market and downsizing the bureaucracy, it chose to follow a series of ad hoc decisions mixed with increasing state intervention and regulation. During the entire life of the plan, Ahmadinejad openly and proudly confessed to economic ignorance and showed an obsessive hostility towards the interest-based banking system. He doggedly pursued certain short-term and populist schemes to lower interest rates in order to create jobs and establish "Islamic social justice" at the expense of planned, long-term projects. Thoroughly immersed in his messianic creed and increasingly convinced of his own self-righteousness, he found the plan to have no relevance in a country "guided by the Twelfth Imam." It was only in the last year of the plan that a major restructuring of the economy called the "great economic surgery," with subsidy reforms as its trail blazer - was introduced and passed by the Majlis. ${ }^{77}$

The absence of a clear economic strategy, combined with gross mismanagement of the economy and aggravated by mounting international censure and the implied threat of military conflict, exerted multiple chilling effects on the economy. Washington's repeated reminders that "all options are on the table" significantly reduced the inflow of foreign funds and new technology needed by industry and agriculture. The hostile climate undermined the Iranian government's own efforts to obtain financing and knowhow from normal sources and scared Iranian investors enough to prompt them to move their funds and businesses abroad. ${ }^{78}$ In short, the absence of economic security at home and the regime's gross mishandling of foreign relations, combined with the Fourth Plan's own inherent shortcomings, left no chance for success.

\footnotetext{
${ }^{1}$ For the plan's text and provisions in Persian, see Qanoon-e Barnameh-e Chaharom-e Tossee Eqtesadi, Ejtemai, va Farhangi-e Jomhouri-e Eslami-e Iran (Tehran: Sazeman-e Modiriyat va Barnameh, 1384 [Management and Planning Organization, 2005).
} 
${ }^{2}$ For a discussion and analysis of this document, see Jahangir Amuzegar, "Iran's 20-Year Economic Perspective," Middle East Policy, Vol. 16, No. 3, 2009.

${ }^{3}$ For a reference to this problem, see www.hamshahrionline.ir/News, July 20, 2010.

${ }^{4}$ A Majlis deputy actually accused the Central Bank of doctoring national economic data to support government claims (see Kayhan [London] July 21, 2010). One of the grand ayatollahs in Qom also later openly questioned the veracity of the Central Bank's data on inflation, and Qom's Friday imam has rejected government data on unemployment. See www.radiofarda.com, September 10, 2010, and September 17, 2010.

${ }^{5}$ www.radiofarda.com, December 25, 2008.

${ }^{6}$ See the full text at www.hamsharionline.ir/News, December 25, 2008. For a documented rebuttal of some of these claims, see http://emruz.net, March 2, 2009.

${ }^{7}$ For a lower estimate, see www.jomhouriestami.com/1389, May 23, 2010.

${ }^{8} \mathrm{http}: / /$ donya-e-eqtesad.com, May 23, 2010.

${ }^{9}$ www.iran-emrooz.net, August 31, 2010.

${ }^{10}$ www.jomhourieslami.com, August 22, 2010.

${ }^{11}$ For a rather detailed calculation of the figures, see www.iran-emrooz.net, August 30, 2010.

${ }^{12}$ www.jomhourieslami.com, May 21, and August 27, 2010.

${ }^{13}$ Iran Statistics Center's rather astonishing figure showing a decline of the national labor force from 41 percent of the population above 10 years of age in 2005 to 39 percent in 2010 may actually reflect these phenomena.

${ }^{14}$ For critical reports about these deviations and misuse of borrowed funds, see http://emruz.net, August 10, 2010.

${ }^{15} \mathrm{http}: / /$ donya-e-eqtesad.com, August 15, 2010.

${ }^{16} \mathrm{http}: / /$ donya-e-eqtesad.com, August 17, 2010.

${ }^{17}$ Aftab website reported in www.radiofarda.com, September 4, 2010.

${ }^{18} \mathrm{http}: / /$ donya-e-eqtesad.com, June 20, 2010.

${ }^{19}$ Iran Economics, July 2010.

${ }^{20}$ www.jomhourieslami.com, April 6, 2010.

${ }^{21}$ www.jomhourieslami.com, May 30, 2010.

${ }^{22}$ For a reference to these and other factors, see www.jomhourieslami.com, August 29, 2010.

${ }^{23}$ A tragic manifestation of this mismatch is a report showing that 1.6 percent of the homeless people in Tehran have college degrees, and 4.7 percent are high school graduates. See Iran Times (Washington), May 14,2010

${ }^{24}$ For a summary discussion of the banking system's capital adequacy and non-performing assets, see Jahangir Amuzegar, “The Rial Problem,” Foreign Policy, February 11, 2010.

${ }^{25}$ See www.radiofarda.com, May 25, 2010.

${ }^{26}$ Total foreign direct investment reported by the head of the Organization for Investment and Foreign Economic and Technical Assistance is $\$ 8.7$ billion for the five years. See http://donya-e-eqtesad.com, September 4, 2010.

${ }^{27}$ www.radioforda.com, January 26, 2009.

${ }^{28}$ www.jomhourieslami.com, July 19, 2010.

${ }^{29} \mathrm{http}: / /$ sarmayeh.net/ShowNews, February 10, May 19, and Jan 19, 2009; and http://donya-e-eqtesad.com/ Nagaresh, May 7, 2009.

${ }^{30}$ www.hamshahrionline.ir, May 22, 2009; http://emruz.net, May 25, 20/09; www.roozonline.com, November 24, 2008; and www.jomhourieslami.com, Feb 21, 2009.

${ }^{31} \mathrm{http}: / /$ donya-e-eqtesad.com, April 28, 2010.

${ }^{32}$ http:// emruz.net, January 4, 2009; and www.payvand.com , October 14, 2009.

${ }^{33}$ www.iran-emruz.net, December 20, 2008.

${ }^{34}$ http://donya-e-eqtesad.com, August 28, 2010.

${ }^{35}$ www.emruz.net, March 8, 2009.

${ }^{36}$ www.jomhourieslami.com/1388, February 15, 2010.

37 http:// donya-e-eqtesad.com, August, 9, 2010.

${ }^{38}$ According to a Tehran Chamber of Commerce official, of the $\$ 18$ billion in non-oil exports in 2008/9, some $\$ 12$ billion consisted of oil-and-gas-based materials. See www.hamshahrionline, March 17, 2009.

${ }^{39}$ www.jomhourieslami.com, September 13, 2010. 
Middle East Policy, Vol. XVII, No. 4, Winter 2010

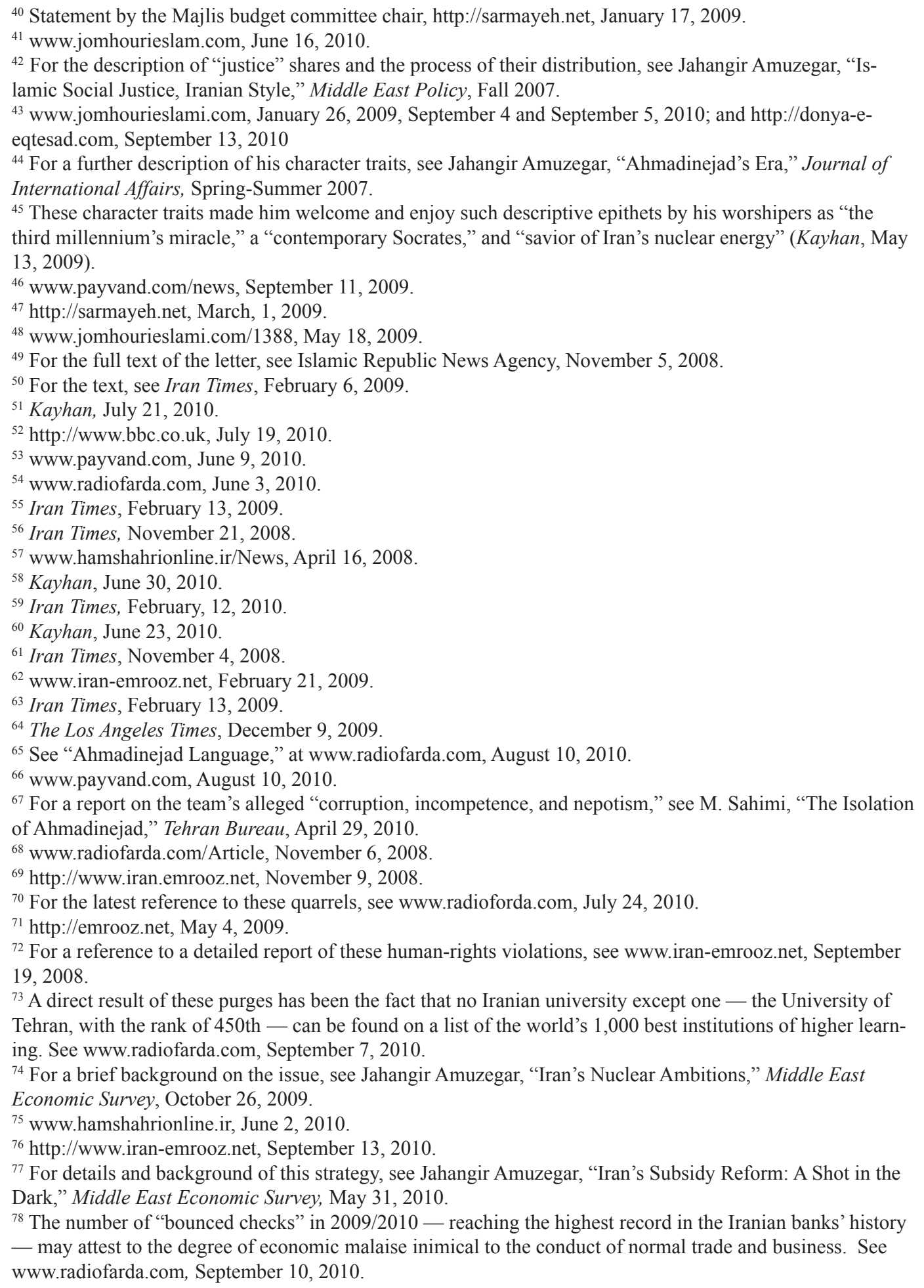

${ }^{40}$ Statement by the Majlis budget committee chair, http://sarmayeh.net, January 17, 2009.

${ }^{42}$ For the description of "justice" shares and the process of their distribution, see Jahangir Amuzegar, "Islamic Social Justice, Iranian Style,” Middle East Policy, Fall 2007

ww.jomhourieslami.com, January 26, 2009, September 4 and Se

${ }^{44}$ For a further description of his character traits, see Jahangir Amuzegar, “Ahmadinejad's Era,” Journal of International Affairs, Spring-Summer 2007.

${ }^{45}$ These character traits made him welcome and enjoy such descriptive epithets by his worshipers as "the 13, 2009).

${ }^{46}$ www.payvand.com/news, September 11, 2009

${ }^{47} \mathrm{http}: / /$ sarmayeh.net, March, 1, 2009.

${ }^{48}$ www.jomhourieslami.com/1388, May 18, 2009

For the full text of the letter, see Islamic Republic News Agency, November 5, 2008

${ }^{51}$ Kayhan, July 21, 2010

52 http://www.bbc.co.uk, July 19, 2010

${ }^{3}$ www.payvand.com, June 9, 2010

www.radiofarda.com, June 3, 2010.

${ }^{56}$ Iran Times, November 21, 2008.

${ }^{57}$ www.hamshahrionline.ir/News, April 16, 2008.

Iran Times, February, 12, 2010

${ }^{62}$ www.iran-emrooz.net, February 21, 2009

${ }^{63}$ Iran Times, February 13, 2009.

${ }^{64}$ The Los Angeles Times, December 9, 2009.

See "Ahmadinejad Language," at www.radiofarda.com, August 10, 2010

${ }^{66}$ www.payvand.com, August 10, 2010.

${ }^{67}$ For a report on the team's alleged "corruption, incompetence, and nepotism," see M. Sahimi, "The Isolation of Ahmadinejad," Tehran Bureau, April 29, 2010.

${ }^{68}$ www.radiofarda.com/Article, November 6, 2008

${ }^{69} \mathrm{http}: / / w w w . i r a n . e m r o o z . n e t$, November 9, 2008

${ }^{70}$ For the latest reference to these quarrels, see www.radioforda.com, July 24, 2010

${ }^{71} \mathrm{http}: / /$ emrooz.net, May 4, 2009.

${ }^{72}$ For a reference to a detailed report of these human-rights violations, see www.iran-emrooz.net, September 19,2008

${ }^{73}$ A direct result of these purges has been the fact that no Iranian university except one - the University of Tehran, with the rank of 450th - can be found on a list of the world's 1,000 best institutions of higher learnSee www.radiofarda.com, September 7, 2010

${ }^{74}$ For a brief background on the issue, see Jahangir Amuzegar, "Iran's Nuclear Ambitions," Middle East

${ }^{76} \mathrm{http}: / / w w w . i r a n-e m r o o z . n e t$, September 13, 2010.

${ }^{77}$ For details and background of this strategy, see Jahangir Amuzegar, "Iran's Subsidy Reform: A Shot in the Dark," Middle East Economic Survey, May 31, 2010.

${ }^{78}$ The number of "bounced checks" in 2009/2010 — reaching the highest record in the Iranian banks' history www.radiofarda.com, September 10, 2010. 